Diabetologia 10, 13-17 (1974)

(C) by Springer-Verlag 1974

\title{
In Vivo Studies on 5-Hydroxytryptamine and Insulin Secretion in Dogs and in Man*
}

\author{
G. Federspil, D. Casara, S. Pedrazzoli, N. Sicolo, and C. Scandellari \\ Institute of Semeiotica Medica, and Institute of Clinica Chirurgica, Padua University, Padua, Italy \\ Received: October 1, 1972; and in revised form: August 13, 1973
}

\begin{abstract}
Summary. 5-Hydroxytryptamine (5-HT) effects on the insulin secretion of anaesthetized dogs and of humans were studied. From our investigations the following conclusions can be drawn: 5-HT when injected at a dose of $4.30 \mathrm{mg}$ into the pancreatic artery, elicits a sharp rise of insulin concentration in pancreatico-duodenal vein; on the contrary, $21.50 \mathrm{mg}$ of $5-\mathrm{HT}$ is unable to modify insulin release. The infusion in fasting man of small amounts of 5 -HT ( $0.50 \mu \mathrm{g} / \mathrm{kg} / \mathrm{min}$ ) during $1 \mathrm{~h}$, does not alter blood glucose nor plasma insulin levels; a similar infusion, however, increases insulin response after oral glucose load.
\end{abstract}

The results obtained in dogs are in agreement with the idea that 5-HT may modulate insulin release from the pancreas. The results in man suggest that enteramine released by the intestine may increase insulin secretion induced by the ingestion of glucose, through a fine interplay with other gut-factors.

Key words: Beta-cell, beta-granules, enteramine, glucose, gut-factors, insulin, insulin secretion, 5-hydroxytryptamine.
5-Hydroxytryptamine (5-HT) is an amine present in several tissues which has been supposed to play a role in several physiological functions, such as regulation of blood pressure, blood coagulation and cerebral neurotransmission.

Several investigations have shown that 5-hydroxytryptamine, in vitro, modifies insulin release from pancreatic tissue and/or from pancreatic microdissected islets $[9,10,14,23,24]$. Moreover it has been shown recently that 5-HT is present in pancreatic beta-cells [1] and Ekholm et al. [4] have shown that 5-HT formed from the administered precursor 3H-5HTP, is mainly confined to the secretory granules of the beta and alpha cells.

All these results are in agreement with the hypothesis that 5-HT may play a physiological role upon insulin secretion [23, 27].

In 1970 it was observed in our laboratory that in a patient with carcinoid tumour, insulin release after oral and i.v. glucose was extremely poor and carbohydrate tolerance was frankly diabetic in type [25].

The present research has been undertaken to ascertain whether insulin secretion in dogs and man, in vivo, is affected by 5-HT.

\section{Methods}

\section{Studies in Dogs}

The experiments were carried out on mongrel dogs, anaesthetized with Nembutal after overnight fasting. Mean weight of the dogs was $18 \pm 3 \mathrm{~kg}$.

The animals were prepared in the following way: after anaesthesia a right subcostal laparatomy was

* This research was supported by C.N.R. grant 71 . $00771 / 04115.1187$. performed and the pancreatico-duodenal vein (p.d.v.) was isolated and cannulated proximally and distally. The two cannulas were then connected by means of a triple branching tap. An interval of 10 min was left between cannulation of the vein and the actual beginning of the experiment itself to allow irregularities of blood flow to disappear.

Samples of blood flowing from the p.d.v. were obtained without stasis from the third branch of the tap.

The femoral vein of the animal was isolated at the same time; a catheter was inserted into this vessel from which blood samples were taken.

5-HT was injected into the pancreatic artery.

$4.30 \mathrm{mg} 5$-HT was injected in two minutes, $20^{\prime}$ after cannulation, into the pancreatic artery of 8 dogs. $20 \mathrm{~min}$ later $21.50 \mathrm{mg}$ 5-HT was injected.

Blood was taken from the pancreatico-duodenal vein and from the femoral vein.

In another two dogs $4.30 \mathrm{mg} 5$-HT was injected, for the second time, $40 \mathrm{~min}$ after the beginning of the experiment.

\section{Studies in Man}

Two types of experiments were carried out in man. All subjects undergoing these studies were free from endocrine diseases and had fasted overnight before the experiment. A) in 6 subjects, 5 males and $1 \mathrm{fe}$ male (mean weight: $67.6 \pm 2.8 \mathrm{~kg}$; mean age $54 \pm 6$ years), $2.15 \mathrm{mg}$ of 5 -HT dissolved in $500 \mathrm{ml}$ saline solution was infused i.v. in $60 \mathrm{~min}$.

Blood samples were taken from the antecubital vein at $0^{\prime}, 15^{\prime}, 30^{\prime}, 45^{\prime}, 60^{\prime}$, and $90^{\prime}$ min from the start of the infusion. B) in 3 male and 6 female subjects (mean weight $70.5 \pm 5.2 \mathrm{~kg}$; mean age $34.8 \pm 4.6$ years) an oral glucose tolerance test $(100 \mathrm{~g})$ was performed. $2-4$ days after the initial test the oral glucose load was repeated. 
During the first $60 \mathrm{~min}$ of the second test $2.15 \mathrm{mg} 5$ HT was infused i.v. in the same way as described above.

\section{Analytical Procedures}

Blood glucose was determined by the enzymatic glucose-oxidase method (Boehringer-Mannheim).

Plasma insulin concentration was measured in triplicate by the Hales and Randle method, as modified by Crepaldi et al. (1966).

Human insulin was used as standard in the radioimmunoassay.

\section{Statistical Evaluation}

Significance has been computed by the method of "Combined Tests" [16] using the combination method. $\chi^{2}$.

According to this method the probabilities associated with the " $t$ " of Student obtained on each subject have been combined.

The value obtained in dogs was $\chi^{2}=21.88$. This value is greater than 18.47 , i.e. the critical value of significance to $1 \%$ of the theoretical $\chi^{2}$ for 7 degrees of freedom.

This statistical method is based on the following steps:

1. for every value obtained from the " $t$ " test the probability of obtaining an inferior value is calculated (in accordance with cumulative distribution);

2. the normal standardized equivalent value is calculated;

3. the sum of the squares of the previous values is considered. This combined test follows the law $\chi^{2}$.

\section{Results}

\section{Experiments in Dogs}

$4.30 \mathrm{mg}$ 5-HT base injected into the pancreatic artery produces an immediate and sharp increase of plasma insulin in the pancreatico-duodenal vein (Fig. 1). ${ }^{1}$ This increase is clearly visible 3 min after injection and is statistically significant $(p<0.01)$.

A much greater amount of 5 -HT however $(21.50$ $\mathrm{mg}$ ), did not produce the same phenomenon and insulinaemia remains unchanged. On the other hand, neither of the two doses of 5-HT appreciably modified insulin concentration in the peripheral veins.

However, blood glucose did appreciably increase after administration of the larger dose of 5-HT.

1 In another series of experiments on dogs, blood flow of the pancreas was measured after an injection of 5 -HT $(4.30 \mathrm{mg})$. The results obtained show that the flow increases. Increased concentration in the p.d.v. does therefore correspond to an actual increase in pancreatic insulin secretion.
It is doubtful whether the lack of an insulin-secreting effect after the large dose of 5-HT may be ascribed to the small burst of insulin induced by the preceding 5-HT injection. This is confirmed by the fact that a second injection of $4.30 \mathrm{mg}$ of 5.HT given to two dogs $20 \mathrm{~min}$ after the first administration produced a rapid insulin increase in p.d.v. (Fig. 2).

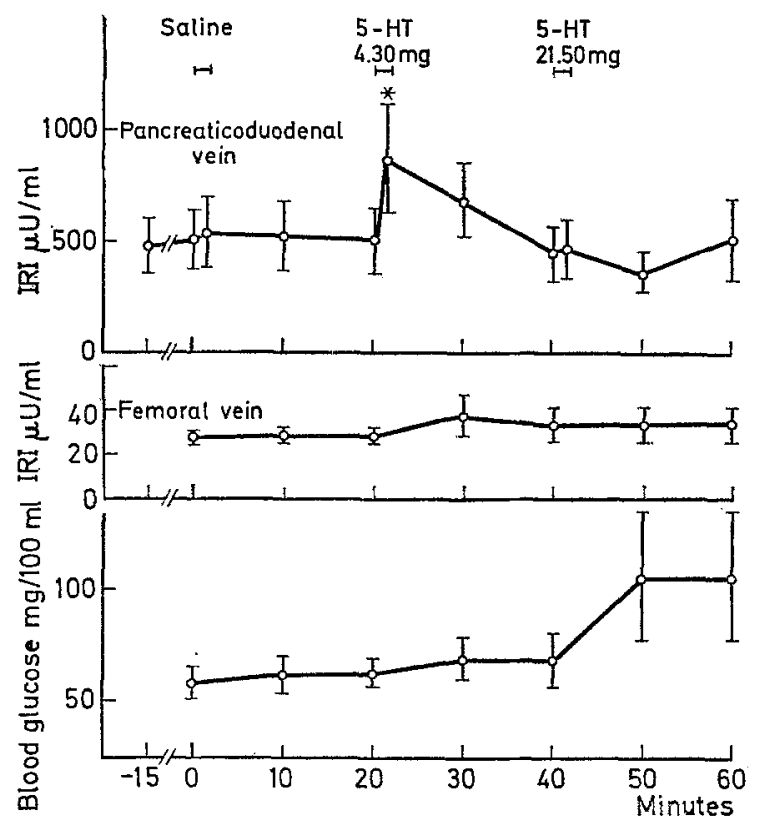

Fig. 1. Effects of 5-HT injected into the pancreatic artery at two different doses $(4.3 \mathrm{mg}$ and $21.5 \mathrm{mg})$ during a $2 \mathrm{~min}$ period.(Vertical bars indicate \pm 1 S.E.; $*: P<0.01$ ) in fasting dogs

\section{Experiments in Man}

In man, 5-HT infused in small quantities for $60 \mathrm{~min}$ after overnight fasting did not appreciably alter glycaemia and insulinaemia (Fig. 3). But when 5-hydroxytryptamine was infused in the first $60 \mathrm{~min}$ after ingestion of glucose, insulin in peripheral blood increased to a greater extent than during the control oral glucose tolerance test (Fig. 4).

Glycaemia was not altered to any appreciable extent by administration of 5 -HT.

\section{Discussion}

In recent years it has been reported that 5-HT stimulates hormone production by several endocrine glands and the hypothesis has been suggested that catechol- as well indol-amines may play a role in the synthesis and/or release of the hormone synthetized in these cells [24].

Only in the last ten years it has been suggested that there is a link between 5-HT and pancreatic islets. The presence of biogenic amines and of 5-HT in the pancreas of several species was established by several 
investigators $[1,7]$. It has been stated that beta-cells possess a transport system with a great capacity for 5-HT [13]. It has also been shown that the pancreatic beta-cells can concentrate, in vivo, both 5-hydroxytryptophan [17] and 5-hydroxytryptamine [8, 20], although to a slight extent in comparison to aminoacid; but it has been stated that a high dose of 5-HT can be taken up relatively more avidly. creatic artery. This effect is closely related to the dose: while the insulin increase is evident with $4.30 \mathrm{mg}$, no increase of insulin concentration in the pancreaticoduodenal vein was observed when five times this dose was injected. These results obtained in vivo are in agreement with the observations in vitro of Telib et al. [23] and suggest a dose-dependent effect of 5-HT on insulin secretion.
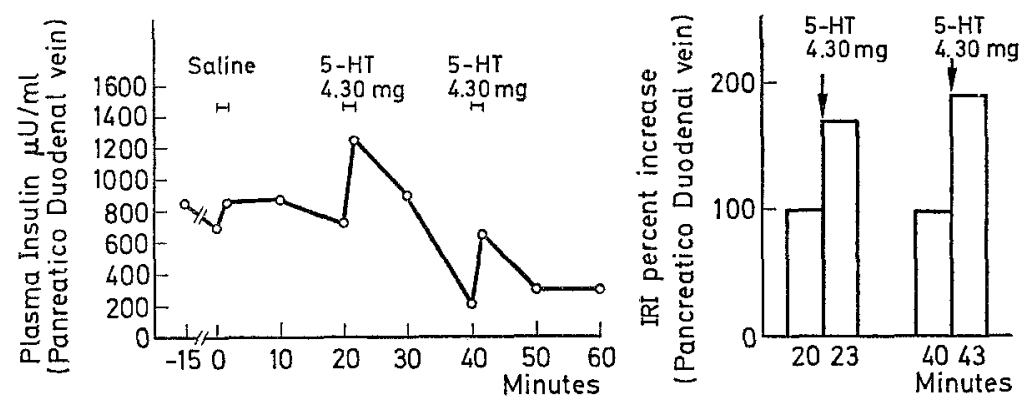

Fig. 2. Fffects of two $4.3 \mathrm{mg}$ injections of 5-HT on plasma insulin level in fasting dogs

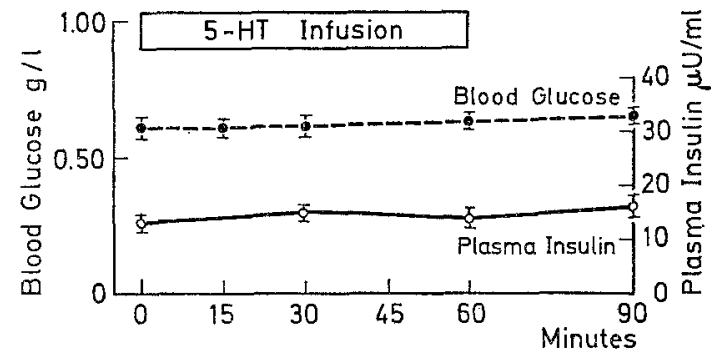

Fig. 3. 5-HT infusion ( $2.15 \mathrm{mg}$ in $60 \mathrm{~min}$ ) in fasting man. (Vertical bars indicate \pm 1 S.E.)

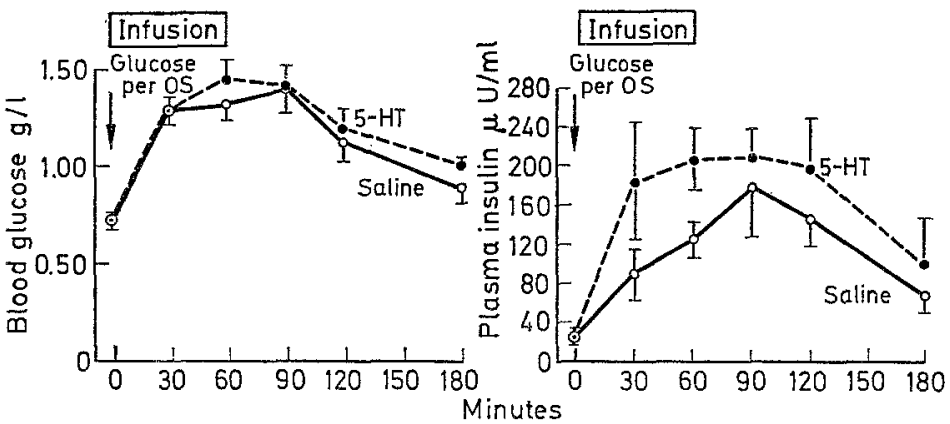

Fig. 4. Effects of 5-HT on blood glucose and plasma insulin levels after oral glucose load in man. Each subject received a control glucose load $(100 \mathrm{~g})$ and a saline infusion; on another occasion each subject received the same glucose load and the 5 -HT infusion $(2.15 \mathrm{mg}$ in $60 \mathrm{~min}$ ). (Vertical bars indicate \pm 1 S.E.)

These observations raise the question of the biological significance of 5-HT with regard to insulin secretion. In recent years it has been shown that 5-HT, in vitro, may play a role in controlling insulin secretion $[9,10$, $14,23,24,27$ ], although different results have been observed in various species. Finally, it has been shown that various doses of the amine may have different effects on insulin secretion $[23,24]$.

Our results indicate that $5-\mathrm{HT}$ rapidly stimulates insulin release in dogs, if it is injected into the pan-
At present, the mechanism of 5-HT on insulin secretion cannot be explained. Coore et al. [2] observed that 5-HT has no apparent effect on the stability of isolated beta-granules. Quay [19] put forward the hypothesis that some of the biological actions of 5hydroxytryptamine may be functionally associated with microtubules in the mechanism of cytoplasmic movement. According to this concept it is possible to maintain that the 5-HT contained in the pancreatic betacells is in some way connected to the beginning of the 
contraction of the microtubular-microfilamentous system and to the displacement of the granules to the cell surface. However an alternative hypothesis may be suggested. In fact, 5 -HT seems to be a substance which. increases the $3^{\prime}-5^{\prime}$ cAMP $[15,21]$; the effect of injected 5-HT may be regarded therefore as an effect on the cell membrane of the beta-cell, increasing adenyl cyclase activity.

To evaluate our results in man, the question of the significance of the doses employed must first be considered. While very large, unphysiological doses of 5 HT were injected into the pancreatic artery of dogs, we believe that the dose employed in humans was rery small.

The quantity of 5-HT in the whole body of a human adult can be estimated at approximately 5-10 $\mathrm{mg}$ [12]. 5-HT is rapidly metabolized and its half-life has been evaluated at about $17 \mathrm{~h}$ in the stomach and $11 \mathrm{~h}$ in the intestine [26]. Since production of 5-HT, when evaluated on the basis of daily urinary excretion seems to be in the order of $5-20 \mathrm{mg} /$ day, the total amount of this amine in the blood $(\sim 1 \mathrm{mg})$ must be renewed several times during the day [5].

Bearing these data in mind, we believe that the amount administered in our experiments in man $\mathbf{2 . 1 5}$ $\mathrm{mg}$ of 5 -HT base, i.e. $0.50 \mu \mathrm{g} / \mathrm{kg} / \mathrm{min}$ ), may be considered as an acceptable physiological dose.

Our results in humans after overnight fasting show that 5-HT infusion does not appreciably alter blood glucose and plasma insulin concentration. On the other hand, when 5-HT is infused immediately after ingestion of glucose, insulin response is clearly greater than that observed in the same subjects after ingestion of glucose alone (Fig. 3-4). This phenomenon is in agreement with the concept that 5-HT plays a physiological role in modulating insulin secretion after a glucose meal, probably through an extracellular action on beta cells, similar to that of enterohormones.

In effect, the greater part of 5-HT present in the body is found in the enterochromaffin cells of the gastrointestinal tract [22] and these cells are in man the only source of circulating 5-HT [6]. 5-HT increases in the peripheral blood in the $\mathbf{3 0}$ min after taking food [11].

The discrepancy between the lack of effect of 5-HT after overnight fasting and the powerful insulin-secreting effect after glucose, could be explained as a synergism of the 5-hydroxytryptamine, with other intestinal factors, on the pancreatic beta-cells ${ }^{2}$.

Acknowledgements. The authors express their thanks to Dr. F. Pesarin for statistical analysis of the data and to Mr. Ernesto Pedini for his excellent technical assistance in these studies.

2 These results were presented in part at the 8 th Annual Meeting of the European Association for the study of Diabetes, Madrid 1972.

\section{References}

1. Cegrell, L.: The occurence of biogenic monoamines in the mammalian endocrine pancreas: a comparative study. Acta physiol. scand. suppl. 314, 1-60 (1968)

2. Coore, H.G., Hellman, B., Pihl, E., Täljedal, I.B.: Physicochemical characteristics of insulin secretion granules. Biochem. J. 111, 107-113 (1969)

3. Crepaldi, G., Scandellari, C., Trisotto, A., Tiengo, A. Federspil, G., Muggeo, M., Avogaro, P.: A simplified method of insulin radioimmunoassay. Acta Isot. 6, 373-391 (1966)

4. Ekholm, R., Ericson, L.E., Lundquist, I.: Monoamines in the pancreatic islets of the mouse. Diabetologia 7, 339-348 (1971)

5. Erspamer, V.: Il sistema cellulare enterocromaffine e l'enteramina. Rendiconti scientifici Farmitalia 1, 5$180(1954)$

6. Erspamer, $\nabla$. : Occurrence of indolealkylamines in nature. In : 5-HT and related indolealkylamines, $p$. 132 (Ed. by Erspamer, V.). Springer-Verlag 1966

7. Falk, B., Hellman, B.: A fluorescent reaction for monoamines in the insulin producing cells of the guinea pig. Acta endocr. (Kbh.) 45, 133-138 (1964)

8. Falk, B., Owman, C.: 5-Hydroxytryptamine and related amines in endocrine cell systems. Advances in Pharmacology 6 A, 211-231 (1968)

9. Feldman, J.M., Lebovitz, H.E.: Serotonin inhibition of in vitro insulin release from golden hamster pancreas. Endocrinology 86, 66-70 (1970)

10. Gagliardino, J.J., Zieher, L.M., Iturriza, F.C., Hernandez, R.E., Rodriguez, R.R.: Insulin release and glucose changes induced by serotonin. Horm. Metab. Res. 3, 145-150 (1971)

11. Geoffroy, M. Y., Matray, F., Moreau, J., Deshayes, P. Fablet, J.: Les variations de la sérotonine sanguine après sollicitation orale. Arch. Mal. App. Digestif T. 53, 341-358 (1964)

12. Goodman, L.S., Gilman, A.: 5-Hydroxytryptamine. From "The pharmacological basis of therapeutics", p. 645. New York. Mac Millan Company 1970

13. Hellman, B., Lernmark, Å., Sclin, J., Täljedal, I.: Transport and storage of 5-hydroxytryptamine in pancreatic beta cells. Biochem. Pharmacol. 21, 695-706 (1972)

14. Lernmark, A.: The significance of 5-hydroxytryptamine for insulin secretion in the mouse. Horm. Metab. Res. 3, 305-309 (1971)

15. Park, C.R., Smeyd, J.G.T., Corbin, J.D., Jefferson, L.S., Exton, J.H.: Role of the cyclic adenylate in the actions of insulin. In: Diabetes (Ed. Ostman, J.) pp. 5-15. Amsterdam: Excerpta Medica Foundation 1969

16. Pesarin, F.: Sui tests combinati e su una carta di controllo multivariata. Atti Convegno Ass. It. controllo della qualità. $\mathrm{AICQ}$ (1973), (in press)

17. Petkov, P.: De l'activité monoaminooxidasique dans le pancreas de l'homme et de certain mammifères: rat blanc, cobaye, chat et lapin. Ann. Histochim. 10, 17$24(1965)$

18. Pfeiffer, E.F.: Intestinal factors controlling insulin secretion. In: Diabetes, pp. 419-424 (Ed. Ostman, J.) Amsterdam: Excerpta Modica Foundation 1969

19. Quay, W.B.: Comparative physiology of serotonin and melatonin. In: Advances in Pharmacology 6 A, 283297 (1968)

20. Ritzén, M., H'ammerström, L., Ullberg, S. : Autoradiographic distribution of 5 -hydroxytryptamine and 5 hydroxytryptophan in the mouse. Biochem. Pharmacol. 14, 313-321 (1965)

21. Robison ,G.A., Butcher, R.W., Sutherland, E.W. Cyclic AMP, p. 380. New York: Academic Press 1971 
22. Samson-Wright: Applied Physiology, p. 529. London: Oxford University Press 1971

23. Telib, M., Raptis, S., Schröder, K.E., Pfeiffer, E.F.: Serotonin and insulin release in vitro. Diabetologia 4 , 253-256 (1968)

24. Tjälve, H.: Catechol- and indolamines in some endocrine cell systems. Acta physiol. scand. suppl. 360, 5$122(1971)$

25. Trisotto, A., Frezzato, S., Federspil, G., Scandellari, C.: Tolleranza ai carboidrati e risposta insulinica in un caso di carcinoide. Minerva med. (Torino) 61, 680$683(1970)$
26. Udenfried, S., Weissbach, H.: Turnover of 5-hydroxytryptamine in tissues. Proc. Soc. exp. Biol. (N.Y.) 97, $748-750(1958)$

27. Ui, M. : Serotonin effect on carbohydrate metabolism. Endocr. jap. 9, 22-32 (1962)

Dr. G. Federspil

Istituto di Someiotica Medica

Via Ospedale Civile 43

I-35100 Padova

Italy 